\title{
Heine Diferansiyel Denkleminin Komütativite Koşulları
}

\author{
Mehmet Emir Köksal \\ Ondokuz Mayis University, Department of Mathematics, 55139, Samsun, Turkey (ORCID: 0000-0001-7049-3398)
}

(Bu yayın 26-27 Haziran 2020 tarihinde HORA-2020 kongresinde sözlü olarak sunulmuştur.)

(DOI: $10.31590 /$ ejosat.779727)

ATIF/REFERENCE: Köksal, M.E. (2020). Commutativity Conditions of Heine's Differential Equation. Avrupa Bilim ve Teknoloji Dergisi, (Special Issue), 239-243.

\section{$\ddot{O} \mathbf{z}$}

Çoğu mühendislik sistemlerinin gerçekleştirilmesi, daha basit sistemlerin ardışık bağlantıları ile yapılmaktadır. Bu durum elektrik ve elektronik sistemlerinin tasarımında çok önemlidir. Her ne kadar bu alt sistemlerin bağlantı sırası, kullanılan özel tasarım yöntemlerine, mühendislik tecrübesine, alışlagelmiş sentez yöntemlerine bağlı olmakla beraber, hassasiyet, kararlılık, doğrusallık, gürültüden etkilenme ve dayanıklılık hususları göz önüne alındığında toplam sistemin ana fonksiyonunu değiştirmeden alt sistemlerin bağlantı sırasının değiştirilmesi (komütativite) pozitif sonuçlara yol açabilmektedir. Bu nedenle pratik uygulamalar açısından komütativite çok önemlidir. Bu çalışmada, Heine diferansiyel denkleminin komütativitesi ele alınmıştır. Bir Heine diferansiyel denklemi ile modellenen sistemin, denklemin parametrelerine bağlı olarak komütatif bir çifti olduğu ya da olmadığı gösterilmiş̧tir. Komütatif olabilmesi için gerekli ve yeterli koşullar belirtilmiştir. Uygulama için bir örnek ele alınmıştır. Bu çalışmada başlangıç koşullarının sıfir olduğu varsayılmıştır. Sıfır olmayan başlangıç koşulları (veya geri beslemeli sistemler) için, bu çalışmada türetilen Heine diferansiyel sistemleri için komütativite koşullarına ek olarak bazı ilave koşullar gereklidir. Sıfır olmayan başlangıç koşulları durumu, genel ikinci dereceden sürekli zamanla değişen doğrusal sistemler için literatürde (Koksal, 2019) daha önce çalışılmış olduklarından bu makalede bunun üzerinde orijinal sonuçlar elde etmemektedir. Komütativite varlığının koşullarını sağlayan bazı parametreler için komütatif Heine diferansiyel denklem çiftleri elde edilmiştir ve bunların Heine tipi olmadığı görülmüştür. Bu nedenle, Heine diferansiyel sistemlerinin komütatif çiftleri, komütatif çiftlerle ilgili keyfi sabitlerin genel seçimi için Heine tipi değildir.

Anahtar Kelimeler: Komütativite, Analog Sistemler, Heine Diferansiyel Denklemi, Zamanla Değişen Sistemler.

\section{Commutativity Conditions of Heine's Differential Equation}

\begin{abstract}
The realization of many engineering systems consists of cascade connection of systems of simple orders, which is very important in design of electrical and electronic systems. Although the order of connection of the systems mainly depends on the special design approach, engineering ingenuity, traditional synthetic methods, when the sensitivity, stability, linearity, noise disturbance, robustness effects are considered the change of the order of connection without changing the main function of the total system (commutativity) may lead positive results. Therefore, the commutativity is very important from the practical point of view. In this paper, commutativity of Heine differential equation is considered. It is shown that the system modeled by a Heine differential equation has a commutative pair or not depending on the parameters of the equation. The conditions that must be satisfied for the commutativity are set in this contribution. An example is considered for application. The initial conditions are assumed to be zero in this study. For the nonzero initial conditions (or for unrelaxed systems), some further relations should hold in addition to the commutativity conditions for relaxed Heine differential systems derived in this paper. The case of nonzero initial conditions do not gain original results on the paper since they have already been studied in the literature (Koksal, 2019) for general second-order continuous-time linear timevarying systems. The commutative pairs of Heine differential equation are obtained for some parameters satisfying the existence conditions of commutativity and it is seen that they are not of Heine type. So, the commutative pairs of Heine differential systems are not Heine type for the general choice of arbitrary constants relating the commutative pairs.
\end{abstract}

Keywords: Commutativity, Analog System, Heine's Differential Equations, Time-varying Systems. 


\section{Introduction}

The commutativity is a very important subject concerning engineers and mathematicians. Especially, it places an important role to improve different system performances in system and control design as a main branch of electrical and electronics engineering. For example, commutative subsystems are used in cascade connected and feedback structures to design higher order composite systems for achieving several beneficial properties such as controllability, sensitivity, robustness, and design flexibility.

Firstly, this subject was studied in the literature by E. Marshall in 1982 (Marshall, 1977) for the first-order linear time-varying differential systems. After that, commutativity conditions of second-order (Koksal, 1982), third-order (Koksal, 1985a), and fourthorder (Koksal, 1985b), systems were obtained by M. Koksal in 1982, 1985a and 1985b respectively. After a long time, commutati vity of fifth-order systems (Koksal et al., 2011) was studied by M. Koksal and M.E. Koksal in 2011.

Although most of the famous second-order linear time-varying differential systems were subjected from the commutativity point of view in (Koksal, 2018a, 2018b), Heine's differential equation (Zwillinger, 1997) is not among them. So the purpose of this presentation is to study the commutativity conditions of Heine differential equation; namely

$$
\ddot{y}+\frac{1}{2}\left(\frac{1}{x-e}+\frac{2}{x-h}\right) \dot{y}+\frac{a+b x+c x^{2}+d x^{3}}{4(x-e)(x-f)^{2}(x-h)^{2}} y=0 .
$$

Here $a, b, c, d, e, f, h$ are constants. Note that $\ddot{y}_{A}(t)=\frac{d^{2}}{d t^{2}} y_{A}(t), \dot{y}_{A}(t)=\frac{d}{d t} y_{A}(t)$, and the initial conditions are assumed to be zero.

\section{Commutativity Conditions}

Let $A$ be linear time-varying second-order differential system described by

$$
a_{2}(t) \ddot{y}_{A}(t)+a_{1}(t) \dot{y}_{A}(t)+a_{0}(t) y_{A}(t)=x_{A}(t) ; t \geq 0,
$$

where $x_{A}(t)$ is the independent excitation and $y_{A}(t)$ is the resulting response. For the unique solution of Eq. (2) for $t \geq t_{0}$, it is sufficient that the excitation and the time-varying coefficients $a_{2}(t), a_{1}(t), a_{0}(t)$ be piece-wise continuous functions of time with $a_{2}(t) \not \equiv 0$.

It is shown in (Koksal, 1982) that all the commutative pairs of (2) are obtained by

$$
\left[\begin{array}{l}
b_{2} \\
b_{1} \\
b_{0}
\end{array}\right]=\left[\begin{array}{ccc}
a_{2} & 0 & 0 \\
a_{1} & a_{2}^{0.5} & 0 \\
a_{0} & a_{2}^{-0.5}\left(2 a_{1}-\dot{a}_{2}\right) / 4 & 1
\end{array}\right]\left[\begin{array}{l}
k_{2} \\
k_{1} \\
k_{0}
\end{array}\right]
$$

if the coefficients of $A$ satisfy

$$
-a_{2}^{0.5} \frac{d}{d t}\left[a_{0}-\frac{1}{16 a_{2}}\left(4 a_{1}^{2}+3 \dot{a}_{2}^{2}-8 a_{1} \dot{a}_{2}+8 \dot{a}_{1} a_{2}-4 a_{2} \ddot{a}_{2}\right)\right] k_{1}=0 .
$$

In Eqs. (2) and (3), $k_{2}, k_{1}, k_{0}$ are some constants. Then any commutative pair $B$ of $A$ is described by

$$
b_{2}(t) \ddot{y}_{B}(t)+b_{1}(t) \dot{y}_{B}(t)+b_{0}(t) y_{B}(t)=x_{B}(t) .
$$

If $k_{1}=0$, Eq. (3) is automatically satisfied for any second-order linear time-varying differential system $A$. The case $k_{1}=0$ correspods to a system $B$ through Eq. (3) which can be obtained from $A$ by constant feedback and constant feedforword gains (constant feedback conjugate of $A$ ) (Koksal, et al., 2011). Therefore, every second-order linear time-varying system $A$ has a commutative pair which is its constant feedback conjugate. In this presentation, we look for the commutativity not of this type, so $k_{1} \neq 0$, and the coefficients of $A$ must satisfy

$$
a_{0}-\frac{1}{16 a_{2}}\left(4 a_{1}^{2}+3 \dot{a}_{2}^{2}-8 a_{1} \dot{a}_{2}+8 \dot{a}_{1} a_{2}-4 a_{2} \ddot{a}_{2}\right)=C
$$

for all $t \geq t_{0}$ where $C$ is some constant. 


\section{Commutativity of Heine Differential Equation}

Under the light of the above given theoretical bases, we investigate the commutativity conditions for the Heine differential equations given in (1).

With the coefficients of Heine differential equation in (1)

$$
\begin{gathered}
a_{2}(x)=1, \\
a_{1}(x)=\frac{1}{2}\left(\frac{1}{x-e}+\frac{2}{x-h}\right), \\
a_{0}(x)=\frac{a+b x+c x^{2}+d x^{3}}{4(x-e)(x-f)^{2}(x-h)^{2}} .
\end{gathered}
$$

Because of the fact that derivative of $a_{2}(x)$ is equal to zero, the commutativity condition in Eq. (6) yields

$$
4 a_{0}-a_{1}^{2}-2 \dot{a}_{1}=K
$$

where $K=4 C$ is a constant. Using the formulas of $a_{0}(x), a_{1}(x)$ and $\dot{a}_{1}(x)=-\frac{1}{2}\left[\frac{1}{(x-e)^{2}}+\frac{2}{(x-h)^{2}}\right]$ in Eq. (7), we obtain

$$
\begin{gathered}
\frac{d x^{4}+(c-e d) x^{3}+(b-e c) x^{2}+(a-e b) x-e a}{(x-e)^{2}(x-f)^{2}(x-h)^{2}} \\
-\frac{1}{4}\left[\frac{1}{(x-e)^{2}}+\frac{4}{(x-e)(x-h)}+\frac{4}{(x-h)^{2}}\right]+\left[\frac{1}{(x-e)^{2}}+\frac{2}{(x-h)^{2}}\right]=K .
\end{gathered}
$$

For finding the unknown parameters in the above equation, we equalize the denominators at the left side of the equation. Then, we multiply both sides of the equation by $(x-e)^{2}(x-f)^{2}(x-h)^{2}$ and obtain the following expression:

$$
\begin{gathered}
4\left[d x^{4}+(c-e d) x^{3}+(b-e c) x^{2}+(a-e b) x-e a\right]-4(x-f)^{2}(x-e)(x-h) \\
+3(x-f)^{2}(x-h)^{2}+4(x-f)^{2}(x-e)^{2}=K(x-e)^{2}(x-f)^{2}(x-h)^{2} .
\end{gathered}
$$

So, we obtain a fourth-order and six-order polynomials at the left and right sides of the equation respectively. Because of the fact that the right side of the equation is sixth-order though the left side is fourth-order, $K$ should be equal to zero. We obtain the following equations by equalizing the coefficients:

for $x^{6}$,

$$
K=0
$$

for $x^{5}$,

$$
-2(h+f) K=0
$$

for $x^{4}$,

$$
4 d+3=0
$$

for $x^{3}$,

$$
4 c=4 e d+2 h+6 f+4 e
$$

for $x^{2}$,

$$
4 b-4 e c-4 e h+3 h^{2}+3 f^{2}+4 f h+4 e^{2}+8 f e=0
$$

for $x^{1}$,

$$
4 a-4 e b+8 f e h-6 f h^{2}-2 f^{2} h-8 f e^{2}-4 f^{2} e=0
$$

for $x^{0}$, 


$$
-4 e a-4 f^{2} e h+3 f^{2} h^{2}+4 f^{2} e^{2}=0 .
$$

Arranging these equations, we get

$$
\begin{gathered}
d=-3 / 4, \\
c=\frac{e+6 f+2 h}{4}, \\
b=-\frac{3 e^{2}+2 e(f-3 h)+3\left(f^{2}+h^{2}\right)+4 f h}{4}, \\
a=\frac{-3 e^{3}+6 e^{2}(f+h)+e\left(f^{2}-3 h^{2}-12 f h\right)+2 f h(f+3 h)}{4}, \\
e^{4}-2 e^{3}(f+h)+e^{2}(f+h)^{2}-2 e f h(f+h)+f^{2} h^{2}=0 .
\end{gathered}
$$

These equations indicate that $e, f$ and $h$ can be chosen freely as to satisfy Eq. (12) and $c, b, a$ are expressed in terms of these freely chosen parameters by Eqs. (9-11).

The parameter $d$ must be strictly equal to $-\frac{3}{4}$ as given in Eq. (8).

\section{Application}

As an application, let us consider Eq. (1) such that $f=1$ and $h=0$. For these values, from Eq. (12), we find $e=0$ or 1 .

i) For $e=0$, from Eqs. (9-11), we get

$$
a=0, b=-\frac{3}{4}, c=\frac{3}{2} .
$$

Then, the Heine differential equation reduces to $\ddot{y}+\frac{3}{2 x} \dot{y}-\frac{3}{16 x^{2}} y=0$. For this differential equation, $4 a_{0}-a_{1}^{2}-2 \dot{a}_{1}=0$. So, Eq. (7) is satisfied. Commutative pair of $A$ is obtained through Eq. (3) as

$$
k_{2} \ddot{y}_{B}(t)+\left(\frac{3}{2 x} k_{2}+k_{1}\right) \dot{y}_{B}(t)+\left(-\frac{3}{16 x^{2}} k_{2}+\frac{3}{4 x} k_{1}+k_{0}\right) y_{B}(t)=x_{B}(t)
$$

which is not an Heine differential equation at all.

ii) For $e=1$, from Eqs. (9-11), we get

$$
a=1, b=-2, c=\frac{7}{4}
$$

Then, the Heine differential equation reduces to $\ddot{y}+\frac{1}{2}\left(\frac{1}{x-1}+\frac{2}{x}\right) \dot{y}+\frac{4-8 x+7 x^{2}-3 x^{3}}{16(x-1)^{3} x^{2}} y=0$. For this differential equation, $4 a_{0}-a_{1}^{2}-2 \dot{a}_{1}=0$. So, Eq. (7) is satisfied. Commutative pair of $A$ is obtained through Eq. (3) as

$$
k_{2} \ddot{y}_{B}(t)+\left[\frac{1}{2}\left(\frac{1}{x-1}+\frac{2}{x}\right) k_{2}+k_{1}\right] \dot{y}_{B}(t)+\left[\frac{4-8 x+7 x^{2}-3 x^{3}}{16(x-1)^{3} x^{2}} k_{2}+\frac{1}{4}\left(\frac{1}{x-1}+\frac{2}{x}\right) k_{1}+k_{0}\right] y_{B}(t)=x_{B}(t)
$$

which is not an Heine differential equation at all.

\section{Conclusions}

The conditions for the existence of second or lower order commutative pairs of the Heine differential equation with zero initial conditions are derived in this contribution. It is shown that Heine's system has many second or lower order commutative pairs other than its feedback conjugates obtained from itself by constant feed-forward and constant feed-back gains. The case of nonzero initial conditions do not gain original results on the paper since they have already been studied in the literature (Koksal, 2019) for general second-order continuous-time linear time-varying systems. The commutative pairs of Heine differential equation are obtained for some parameters satisfying the existence conditions of commutativity and it is seen that they are not of Heine type. 


\section{Acknowledgment}

This work was supported by the Scientific and Technological Research Council of Turkey under the project no. $115 \mathrm{E} 952$.

\section{References}

Koksal, M. (1982). Commutativity of second order time-varying systems. International Journal of Control. 3, 541-44.

Koksal, M. (1985a). A survey on the commutativity of time-varying systems. METU, Technical Report. no: GEEE CAS-85/1.

Koksal, M. (1985b). Commutativity of $4^{\text {th }}$ order systems and Euler systems. Presented in National Congress of Electrical Engineers. Paper no: BI-6, Adana, Turkey.

Koksal, M. and Koksal, M. E. (2011). Commutativity of linear time-varying differential systems with non-zero initial conditions: A review and some new extensions. Mathematical Problems in Engineering. 2011, 1-25.

Koksal, M. E. (2018a). Commutativity and commutative pairs of some well-known differential equations. Communications in Mathematics and Applications. 9 (4), 689-703.

Koksal, M. E. (2018b). Commutativity conditions of some time-varying systems. International Conference on Mathematics: "An Istanbul Meeting for World Mathematicians”. 3-6 Jul 2018, Istanbul, Turkey, pp. 109-117.

Koksal, M.E. (2019). Explicit commutativity conditions for second order linear time-varying systems with non-zero initial conditions, Archives of Control Sciences. 29 (3) 413-432.

Marshall, J. E. (1977). Commutativity of time varying systems. Electro Letters. 18, 539-40.

Zwillinger, D. (1997). Handbook of Differential Equations. 3rd ed. Boston, MA: Academic Press, p. 127. 